\title{
Gambaran Perilaku Hidup Bersih dan Sehat (PHBS) Terkait dengan Status Infeksi Kecacingan pada Warga Kampung Serdang, Desa Silebu Kec. Kragilan Kab. Serang Banten Tahun 2019
}

\author{
* Rika Kartika ${ }^{1}$, Sumiati Bedah ${ }^{1)}$, \\ ${ }^{1}$ Prodi Analis Kesehatan, Fakultas Kesehatan, Universitas Mohammad Husni Thamrin, Jakarta \\ *Correspodence author: Rika Kartika, rikaarifin.rka@gmail.com, Jakarta, Indonesia
}

Abstrak

Prevalensi Kecacingan di Indonesia masih sangat tinggi 45-65\%, infeksi kecacingan dapat menimbulkan gangguan pada proses pertumbuhan dan perkembangan. Tujuan penelitian ini untuk mengetahui gambaran Perilaku Hidup Bersih dan Sehat (PHBS) terkait dengan infeksi kecacingan disebabkan oleh Nematoda usus yang ditularkan melalui tanah disebut "Soil Transmitted Helminths/STH" pada warga kampung Serdang, Silebu, Kragilan, Serang, Banten. Kegiatan ini dilakukan pada bulan Desember 2019 berdasarkan data hasil pemeriksaan tinja warga pada penelitian sebelumnya yang dilakukan di laboratorium parasitologi Universitas MH Thamrin.

Metode penelitian digunakan observasional analitik menggunakan kuesioner dan observasi. sampel penelitian kegiatan ini yang bersedia menjadi responden adalah 186 warga, metode analisa data menggunakan persentase. Hasil penelitian ini menunjukan bahwa angka infeksi kecacingan nematoda usus sebanyak $33 \%$ dan perilaku personal hygiene baik $69 \%$. Variabel personal hygiene yang diukur adalah variabel perilaku yang berhubungan dengan infeksi kecacingan yaitu memotong kuku kategori baik 72\%, mencuci tangan sebelum makan kategori baik $83 \%$, pengelolaan sampah kategori baik 65\%, pengelolaan lantai rumah kategori baik 63\%, pengelolaan jamban kategori baik 58\%, pengelolaan air bersih kategori baik 58\%. PHBS dapat dilakukan ditingkatan masyarakat dengan meningkatkan pengetahuan, kesadaran, dan kemauan masyarakat agar hidup bersih dan sehat untuk berperan serta aktif mewujudkan derajat kesehatan yang optimal menawarkan solusi terhadap permasalahan bangsa.

Kata Kunci : Infeksi Kecacingan, Personal hygiene, PHBS

\begin{abstract}
The prevalence of worms in Indonesia is still very high 45-65\%, worm infection can cause disruption in the process of growth and development. The purpose of this study was to determine the description of Clean and Healthy Living Behavior (PHBS) associated with intestinal worms caused by soil-borne intestinal nematodes called "Soil Transmitted Helminths / STH" in residents of the villages of Serdang, Silebu, Kragilan, Serang, Banten. This activity was carried out in December 2019 based on data on the results of fecal examination of residents in previous studies conducted at the MH Thamrin University parasitology laboratory.

The research method used was observational analytic using questionnaires and observations. The research sample of this activity who is willing to become respondents is 186 residents, the data analysis method uses a percentage. The results of this study showed that the intestinal nematode worm infection rate was $33 \%$ and personal hygiene behavior was good $69 \%$. The personal hygiene variables measured were behavioral variables related to worm infections, namely cutting nails, $72 \%$ good category, washing hands before eating, $83 \%$ good category, $65 \%$ good category waste management, $63 \%$ good category house floor management, good category toilet management 58 $\%$, good category clean water management $58 \%$. PHBS can be carried out at the community level by increasing the knowledge, awareness and willingness of the community to live clean and healthy to participate actively in realizing an optimal degree of health offering solutions to the problems of the nation.
\end{abstract}

Keywords: Worms infection, Personal hygiene, PHBS

Open Journal System (OJS): journal.thamrin.ac.id 


\section{PENDAHULUAN}

Diseluruh dunia diperkirakan lebih dari dua milyar orang terinfeksi kecacingan dan 300 juta diantaranya menderita infeksi berat dengan 150 ribu kematian terjadi setiap tahun akibat infeksicacing usus Soil Transmitted Helmints (STH). Penyakit kecacingan tersebar luas dipedesaan dan diperkotaan. Angka infeksinya tinggi, tetapi intensitas infeksinya (jumlah cacing dalam perut) berbeda. ${ }^{1}$ Prevalensi penyakit kecacingan di Indonesia masih sangat tinggi yaitu antara 45-65\% dan menjadi masalah kesehatan masyarakat, bahkan diwilayah-wilayah tertentu dengansanitasi yang buruk prevalensi kecacingan bisa mencapai $80 \%{ }^{2}$

Cacing sebagai hewan parasit tidak saja mengambil zat-zat gizi dalam usus anak, tetapi juga merusak dinding usus sehingga mengganggupenyerapan zat-zat gizi tersebut. Anak-anak yang terinfeksi cacing biasanya mengalami: lesu, pucat/anemia, berat badan menurun, tidak bergairah, konsentrasi belajar kurang, kadang disertai batuk-batuk. ${ }^{2}$

Pencemaran tanah merupakan penyebab terjadinya transmisi telur cacing dari tanah kepada manusia melalui tangan atau kuku yang mengandung telur cacing lalu masuk ke mulut melalui makanan. ${ }^{5}$ Meskipun penyakit cacing usus tidak mematikan, tetapi menggerogoti kesehatan tubuh manusia sehingga berakibat menurunnya kondisi gizi dan kesehatan masyarakat. Dalam jangka panjang, hal ini akan berakibat menurunnya kualitas sumber daya manusia.

Infeksi cacing usus merupakan infeksi kronikyang paling banyak menyerang anak balita dan anak usia sekolah dasar. Derajat kesehatan masyarakat tentnag tinggi rendahnya frekuensi kecacingan berhubungan erat dengan personal hygiene (kebersihan pribadi) dan sanitasi lingkungan. ${ }^{6}$ Cacing-cacing yang menginfestasi anak dengan prevalensi yang tinggi ini adalah cacing gelang (Ascaris lumbricoides), cacing cambuk (Trichuris trichiura), cacing tambang (necator americanus) dan cacing pita, kalau diperhatikan dengan teliti, cacing-cacing yang tinggal di usus manusia ini memberikan kontribusi yang sangat besar terhadap kejadian penyakit lainnya misalnya kurang gizi dengan infestasi cacing gelang yang suka makan karbohidrat dan protein di usus sebelum diserap oleh tubuh, kemudian penyakit anemia (kurang kadar darah) karena cacing tambang mengisap darah di usus, cacing cambuk dan cacing pita suka mengganggu pertumbuhan dan perkembangan anak serta mempengaruhi masalah-masalah 
non kesehatan lainnya misalnya turunnya prestasi belajar. ${ }^{2}$

Tujuan penelitian ini adalah untuk mengetahui gambaran Perilaku Hidup Bersih dan Sehat (PHBS) terkait angka Infeksi kecacingan disebabkan oleh Nematoda usus yang ditularkan melalui tanah atau disebut "Soil Transmitted Helminths/STH" pada warga kampung Serdang, Desa Silebu Kecamatan Kragilan, Kabupaten Serang, Banten

\section{METODE PENELITIAN}

Metode penelitian yang digunakan adalah observasional analitik dengan menggunakan kuesioner dan observasi. Sampel penelitian dalam kegiatan ini yang bersedia menjadi responden adalah 186 dari 195 warga, metode analisa data menggunakan persentase

\section{HASIL PENELITIAN}

\section{Gambaran Umum Lokasi Penelitian}

Kampung Serdang merupakan sebagian Desa Silebu, Kecamatan Kragilan, Kabupaten Serang, Banten. Desa Silebu ini terletak sekitar $\pm 18 \mathrm{~km}$ dari Kabupaten Serang. Luas wilayah Kecamatan Kragilan adalah 51,56 $\mathrm{km}^{2}$. Kecamatan ini terdiri dari 14 Desa/Kelurahan. RT 002 RW 002 Kampung Serdang, Desa Silebu merupakan salah satu kampung yang dikelilingi dengan sawah dan kebun yang jauh dari perkotaan. Kampung Serdang memiliki \pm 400 penduduk.

\section{Analisis hasil}

Dari 195 warga yang telah diperiksa tinjanya (pada penelitian September 2019) hanya 186 yang bersedia ikut dalam kegiatan penelitian dibulan Desember 2019.

Lebih dari setengah responden memiliki personal hygiene yang baik. Untuk mengetahui variable yang terdapat dalam personal hygiene, maka peneliti menampilkan data yaitu memotong kuku, mencuci tangan sebelum makan. Hasil wawancara dengan warga tentang perilaku pencegahan kecacingan menunjukkan bahwa hampir sebagian besar warga mencuci tangan baik sebelum makan dan setelah buang air besar dengan menggunakan sabun, pada hasil observasi langsung dengan memeriksa kuku responden ditemukan hampir tiga perempat responden mempunyai kuku yang kotor walaupun saat menjawab kuesioner memotong kuku masuk kategori baik. 
Hasil wawancara tentang sanitasi lingkungan (pengelolaan sampah, adanya jamban dan pengelolaan air bersih) pada warga menunjukkan bahwa lebih dari setengah masuk kategori baik. Sumber air terbanyak yang digunakan untuk keperluan sehari-hari adalah sumur pompa.

Untuk selengkapnya dapat ditampilkan pada gambar data berikut ini

\section{a). Angka Infeksi Kecacingan Nematoda Usus STH}

Data yang berdasarkan hasil pemeriksaan tinja pada bulan September 2019 dari 195 dan yang bersedia ikut dalam penelitian ini 186 responden. Diperoleh data yang positif infeksi kecacingan sebanyak 83(33\%), dapat dilihat pada gambar 1 dibawah ini.

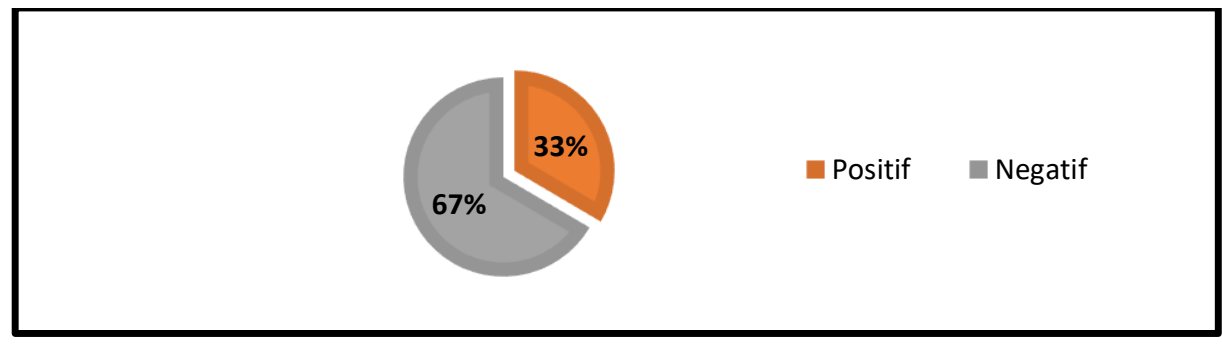

Gambar 1. Distribusi Frekuensi Angka Kecacingan pada warga Kampung Serdang, Desa Silebu, Kec Kragilan, Kab.Serang, Banten 2019

\section{b). Personal Hygiene}

Hasil distribusi frekuensi untuk personal hygiene pada responden dapat dilihat pada gambar 2. Personal hygiene kurang baik 57 (31\%) dan Baik 129 (69\%)

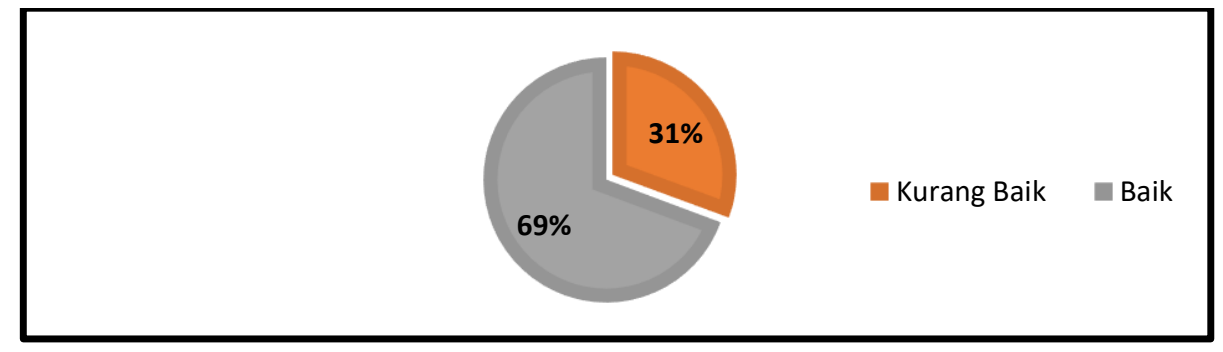

Gambar 2. Distribusi Frekuensi Personal Hygiene pada warga Kampung Serdang, Desa Silebu, Kec Kragilan, Kab.Serang, Banten 2019 


\section{c). Perilaku Memotong Kuku}

Hasil distribusi frekuensi perilaku memotong kuku pada responden seperti terlihat pada gambar 3 . Perilaku memotong kuku kurang baik 52 (28\%) dan baik 134 (72\%)

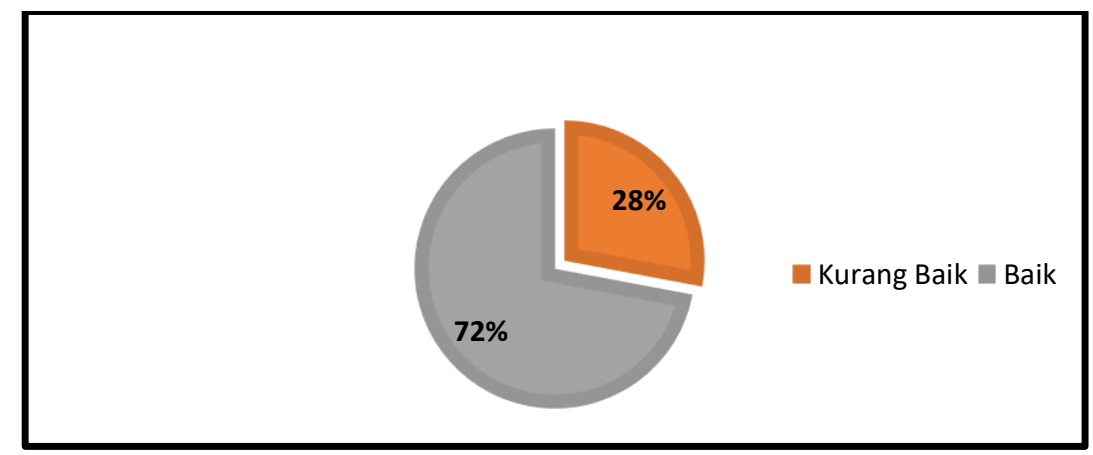

Gambar 3. Distribusi Frekuensi Memotong Kuku pada warga Kampung Serdang, Desa Silebu, Kec Kragilan, Kab.Serang, Banten 2019

\section{d). Perilaku Mencuci Tangan}

Hasil distribusi frekuensi perilaku mencuci tangan pada responden dapat dilihat pada gambar 4. Variabel mencuci tangan kurang baik 32(17\%), Baik 154(83\%)

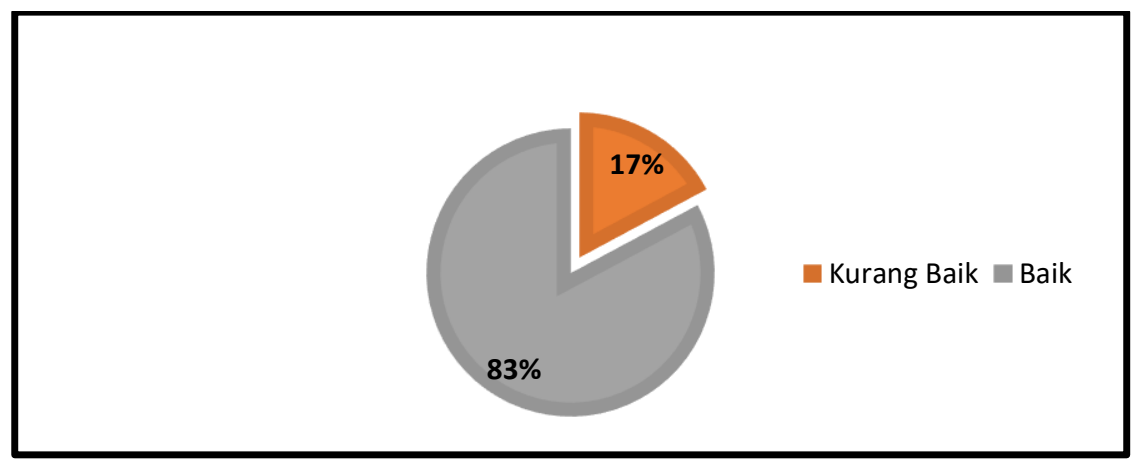

Gambar 4. Distribusi Frekuensi Mencuci Tangan pada warga

Kampung Serdang, Desa Silebu, Kec Kragilan, Kab.Serang, Banten 2019

\section{e). Perilaku Pengelolaan Sampah}

Hasil distribusi frekuensi untuk perilaku pengelolaan sampah pada responden dapat dilihat pada gambar 5. Pengelolaan Sampah Kurang Baik 65(35\%) Baik 121(65\%) 


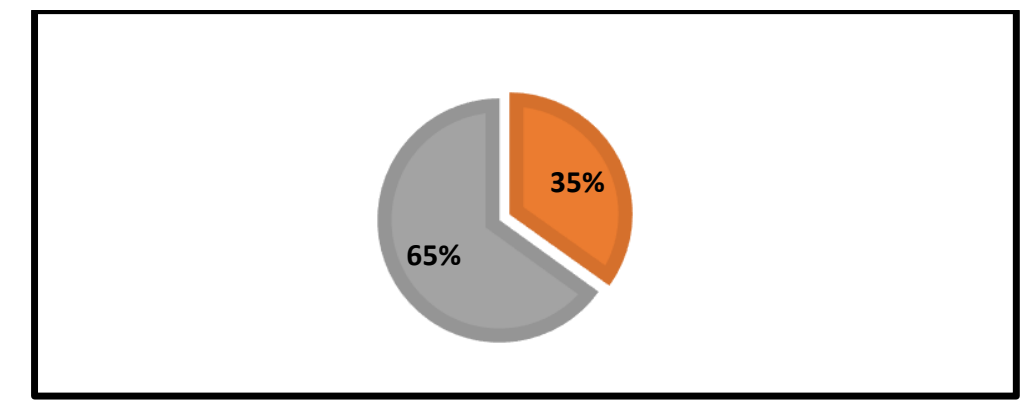

Gambar 5. Distribusi Frekuensi Pengelolaan Sampah pada warga Kampung Serdang, Desa Silebu, Kec Kragilan, Kab.Serang, Banten 2019

\section{f). Keadaan Lantai Rumah (Observasi)}

Hasil distribusi frekuensi keadaan lantai rumah (observasi) pada responden dapat dilihat pada gambar 6 . Pada observasi lantai rumah kurang baik $69(37 \%)$ baik $117(63 \%)$

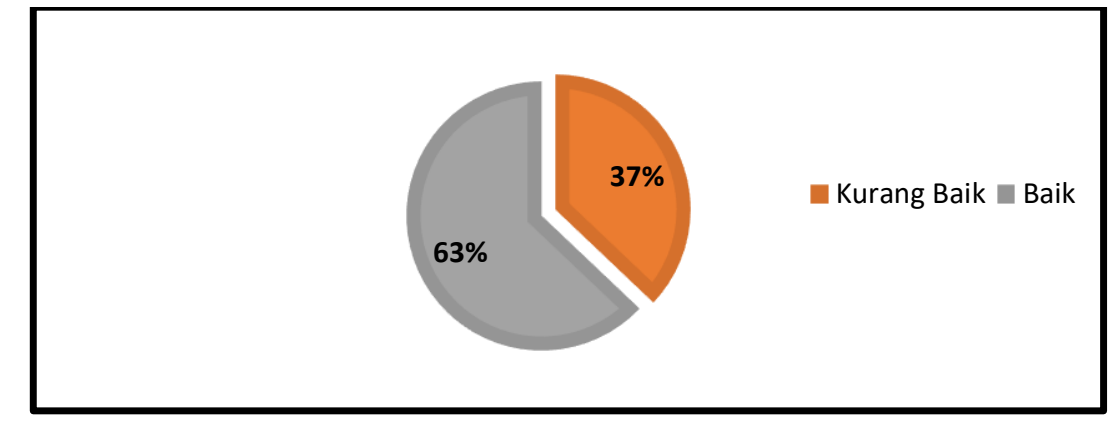

Gambar 6. Distribusi Frekuensi Keadaan Lantai Rumah pada warga Kampung Serdang, Desa Silebu, Kec Kragilan, Kab.Serang, Banten 2019

\section{g). Pengelolaan Jamban}

Hasil distribusi frekuensi pengelolaan jamban pada responden seperti terlihat pada gambar 7. Pengelolaan jamban kurang baik 79(42\%) baik 107(58\%) 


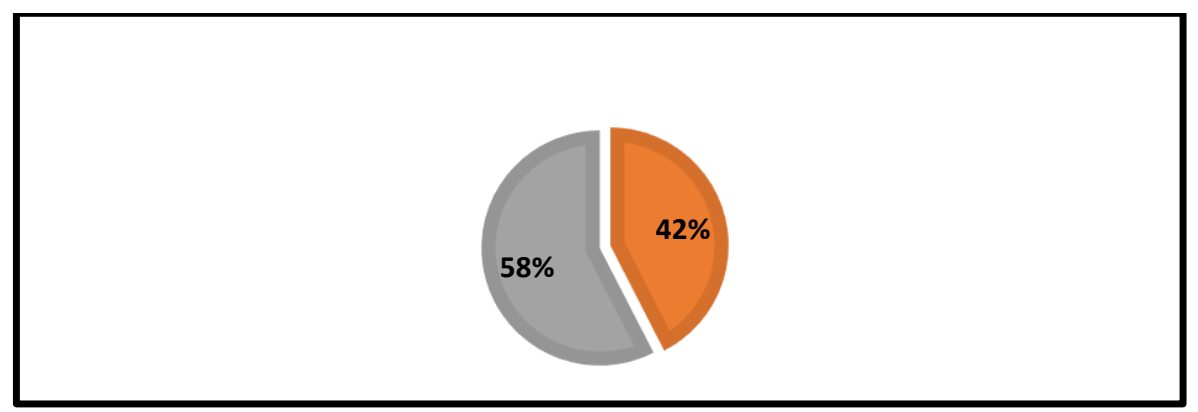

Gambar 7. Distribusi Frekuensi Pengelolaan Jamban pada warga Kampung Serdang, Desa Silebu, Kec Kragilan, Kab.Serang, Banten 2019

\section{h). Pengelolaan Air Bersih}

Hasil distribusi frekuensi pengelolaan air bersih pada responden dapat dilihat pada gambar 8 . Pengelolaan air bersih kurang baik $85(46 \%)$ baik 101(54\%)

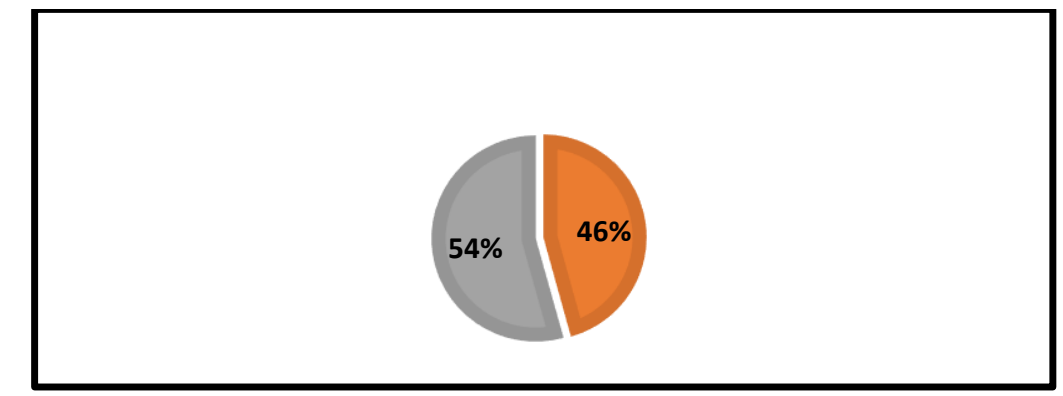

Gambar 8. Distribusi Frekuensi Pengelolaan Air Bersih pada warga Kampung Serdang, Desa Silebu, Kec Kragilan, Kab.Serang, Banten 2019

\section{PEMBAHASAN}

Faktor-faktor penyebab infeksi kecacingan salah satunya adalah personal hygiene. Hal ini sejalan dengan penelitian Adisti Andaruni menunjukkan bahwa faktor-faktor penyebab infeksi kecacingan meliputi personal hygiene, perilaku dan sanitasi lingkungan. ${ }^{15}$ Pengetahuan responden tentang kecacingan memang masih sangat rendah sehingga untuk mengantisipasi agar tidak terkena penyakit ini. juga masih sangat rendah. Pengetahuan merupakan faktor domain yang sangat penting untuk terbentuknya tindakan seseorang.Berdasarkan hasil pemeriksaan sampel tinja pada rseponden diperoleh 83 (33\%) positif terinfeksi kecacimgan. Angka ini termasuk tinggi diatas dari angka nasional kecacingan $10 \%$.

Menurut Soekidjo, seseorang memiliki perilaku pasif yang terjadi di dalam dirinya dan tidak secara langsung dapat terlihat oleh orang lain. ${ }^{16}$ Perilaku yang responden tunjukkan dari hasil wawancara untuk mencegah kecacingan sudah bagus, Hasil penelitian ini menunjukan 
bahwa angka infeksi kecacingan nematoda usus (Soil Trasmitted Helminth/STH) sebanyak 33\% dan perilaku personal hygiene baik $69 \%$. Variabel personal hygiene yang diukur adalah variabel perilaku yang berhubungan dengan infeksi kecacingan yaitu memotong kuku kategori baik $72 \%$, mencuci tangan sebelum makan kategori baik 83\%, pengelolaan sampah kategori baik 65\%, pengelolaan lantai rumah kategori baik 63\%, pengelolaan jamban kategori baik 58\%, pengelolaan air bersih kategori baik 58\%,, tetapi mungkin pada saat prakteknya tidak sesuai dengan jawaban yang diberikan, seperti perilaku mencuci tangan, walaupun resonden menyatakan mencuci tangan sebelum makan tetapi apakah pada saat cuci tangan sudah sesuai dengan pedoman cuci tangan yang benar. Begitu pula dengan perilaku meng- konsumsi kue atau cemilan hasil dari jajan, responden merasa tidak perlu mencuci tangan karena bukan makan nasi sehingga langsung mengkonsumsi makanannya tanpa mencuci tangan terlebih dahulu. Adapun kesenangan responden bermain di tanah $(46,25)$, masih menjadi perilaku yang mendukung terjadinya kecacingan karenakebiasaan responden yang tidak selalu memakai sendal/sepatu pada saat bermain.

Hasil penelitian yang tidak menemukan hubungan antara sanitasi lingkungan dengan kejadian kecacingan pada warga Kampung Serdang, Desa Silebu, Kec Kragilan, Kab.Serang, Banten dengan hasil penelitian yang dilakukan oleh Wachidaniyah yang menemukan adanya hubungan yang bermakna antara kondisi sanitasi lingkungan dengan kejadian kecacingan. ${ }^{17}$ Kesehatan lingkungan pada hakikatnya adalah suatu kondisiatau keadaan lingkungan yang optimum sehingga berpengaruh positif terhadap terwujudnya status kesehatan yang optimal. Adapun ruang lingkup kesehatan lingkungan meliputi: perumahan, pembuangan kotoran manusia, penyediaan air limbah, rumah hewan ternak, dan sebagainya. ${ }^{16}$ Pada penelitian ini ditemukan walaupun responden menyatakan tersedia sabun di dalam jamban namun belum tentu digunakan pada saat setelah Buang air besar (BAB). Perilaku mencuci tangan yang benar yaitu dengan cara mencuci tangan di air mengalir dan memakai sabun dapat menghilangkan berbagai macam kuman dan kotoran yang menempel di tangan sehingga tangan bersih dan bebas kuman. Cucilah tangan setiap kali sebelum makan dan melakukan aktifitas yang menggunakan tangan.

Open Journal System (OJS): journal.thamrin.ac.id 


\section{SIMPULAN}

Angka infeksi kecacingan nematoda usus (Soil Trasmitted Helminth/STH) sebanyak $33 \%$ dan perilaku personal hygiene baik 69\%. Variabel personal hygiene yang diukur adalah variabel perilaku yang berhubungan dengan infeksi kecacingan yaitu memotong kuku kategori baik $72 \%$, mencuci tangan sebelum makan kategori baik $83 \%$, pengelolaan sampah kategori baik 65\%, pengelolaan lantai rumah kategori baik 63\%, pengelolaan amban kategori baik 58\%, pengelolaan air bersih kategori baik 58\%. Perilaku personal hygiene yang berhubungan terjadinya infeksi kecacingan pada warga kampung Serdang, Desa Silebu Kecamatan Kragilan, Kabupaten Serang, Banten sudah baik. Perilaku Hidup Bersih dan Sehat (PHBS) merupakan salah satu solusi untuk mengatasi permasalahan kesehatan di Indonesia. PHBS dapat dilakukan ditingkatan masyarakat dengan meningkatkan pengetahuan, kesadaran, kemauan dan kemampuan masyarakat agar hidup bersih dan sehat untuk berperan serta aktif mewujudkan derajat kesehatan yang optimal menawarkan solusi terhadap permasalahan bangsa. Kegiatan ini merupakan aplikasi penerapan dan penyebarluasan hasil penelitian pada masyarakat sesuai dengan kondisi dan masalah yang ada.

\section{REFERENSI}

Children from rural communities in Honduras [Internet]. PLoS Negl Trop Dis. 2013 [cited 2016 Jan 19]. Available from: http://www.pubmedcentral.nih.gov/articlerender.fcgi?artid=3738480\&tool=pmcentre $z \&$ rendertype $=a$ bstract

Susanto. Buku ajar Parasitologi Kedokteran. Jakarta: Balai Penerbit FK UI; 2008. 4 p.

WHO. Soil-transmitted Helminth Infections Fact Sheet [Internet]. [cited 2016 Jan 19]. Available from: http://www.who.int/mediacentre/f actsheets/fs366/en/

WHO. Soil transmitted helminthiases School age children - National coverage (\%) [Internet]. [cited 2016 Jan 19]. Available from:http://apps.who.int/neglected_dise ases/ntddata/sth/sth.html

DinkesProv. Kecacingan. 2008; Andrauni. Gambaran Faktor- Faktor Penyebab Infeksi Cacingan pada Anak di SDN 01 Pasirlangu Cisarua [Internet]. [cited 2016 Apr 16]. Available from: athttp://www.journals.unpad.ac.id/index.php/ejournal/article/view/5 97

DepKes RI. PPM-PL Tahun 2004.Ditjend PPM-PL. 2004; 
Samad. Hubungan infeksi dengan pencemaran tanah oleh telur cacing yang ditularkan melalui tanah dan perilaku anak sekolah dasar di Kelurahan Tembung Kecamatan Medan Tembung. Tesis. Medan. Pasca Sarj Univ Sumatra Utara. 2009;

Raso. Disparities in parasitic infections, perceived ill health and access to health care among poorer and less poor schoolchildren of rural Cote d'Ivoire. Trop Med Int Heal. 2005;10:42-57.

Endriani. Beberapa faktor yang berhubungan dengan kejadian kecacingan pada anak usia 1-4 tahun. 2011.

Holland. Intestinal helminthiases in relation to the socioeconomic environment of Panamanian children. Soc Sci Med. 1988;26:209-13.

Subarratno. Riau dalam arus perubahan. Alaf Riau. 2004;

Irdianty. Studi Deskriptif Sanitasi Dasar di Tempat Pelelangan Ikan Lempasing Teluk Betung Bandar Lampung. Skripsi Univ Indones. 2011;

Division of Parasitic Diseases and Malaria. Centers for Disease Control and Prevention [Internet]. 2013. Available from: $\quad$ http://www.cdc.gov/dpdx/hookwo rm/gallery.html

DepKes RI. Higiene sanitasi makanan dan minuman. Jakarta: Ditjen PPM dan PL; 2004.

Dinkes Prov. Penilaian Rumah Sehat untuk Puskesmas. Semarang: Seksi Kesehatan Lingkungan; 2005.

Singh. Predictors of intestinal parasitosis in school children of Kashmir: A prospective study. Trop Gastroenterol. 2010;31(2):105-7.

DepKes RI. Pedoman Umum Program Nasional Pemberantasan Cacingan di Era 